\title{
Разупорядочение кристаллической решетки и точечные дефекты в слоях HgCdTe, выращенных методом МЛЭ на подложках $\mathrm{Si}$ и GaAs
}

\author{
К.Д. Мынбаев ${ }^{1,2)}$, Н.Л. Баженов ${ }^{2)}$, Д.А. Андрющенко ${ }^{1)}$, В.С. Варавин ${ }^{3)}$, Н.Н. Михайлов ${ }^{3)}$, \\ Д.В. Марин ${ }^{3)}$, С.А. Дворецкий ${ }^{3)}$, В.Г. Ремесник ${ }^{3)}$, М.В. Якушев ${ }^{3)}$ \\ ${ }^{1}$ Университет ИТМО, Санкт-Петербург, 197101, Кронверкский пр., 49 \\ ${ }^{2}$ ФТИ им. А.Ф. Иоффе, Санкт-Петербург, 194021, Политехническая ул., 26 \\ ${ }^{3}$ ИФП им. А.В. Ржанова СО РАН, Новосибирск, 630090, пр. Ак. Лаврентьева, 13 \\ тел:+7 (812) 292-7182, факс:+7 (812) 247-1017, эл. nочта: karim.mynbaev@ niuitmo.ru
}

DOI 10.34077/RCSP2019-112

Твердые растворы HgCdTe являются важным материалом для изготовления фотоприемников, работающих в инфракрасной области спектра. В силу существенной ионности химических связей, для $\mathrm{HgCdTe}$ характерно значительная плотность дефектов кристаллической решетки, - в том числе, протяженных, связанных с разупорядочением твердого раствора (см., например, [1]), а также точечных. Концентрация подобных дефектов может возрастать в материале, выращенном неравновесными методами, включая широко используемый метод молекулярно-лучевой эпитаксии (МЛЭ). Причины возникновения дефектов, параметры процесса изготовления материала, влияющие на их концентрацию, и возможность снижения этой концентрации пост-ростовой обработкой до сих пор остаются предметом исследований и дискуссий.

Нами были проведены исследования макроскопических дефектов, связанных с разупорядочением кристаллической решетки, а также точечных дефектов, в гетероэпитаксиальных слоях твердых растворов $\mathrm{HgCdTe}$, выращенных МЛЭ на подложках $\mathrm{GaAs}$ и $\mathrm{Si}$. Исследования проводились методами фотолюминесценции (ФЛ) и оптического пропускания (ОП). Для исследований были выбраны образцы $\mathrm{Hg}_{1-\mathrm{x}} \mathrm{Cd}_{\mathrm{x}} \mathrm{Te} \mathrm{c}$ составами (мольной долей $\mathrm{CdTe}$ ) фоточувствительной области гетероэпитаксиальных структур $x=0.35-0.40$, актуальными для создания фотоприемников, работающих в диапазоне длин волн 3-4 мкм. Образцы были выращены в Институте физики полупроводников им. А.В. Ржанова (Новосибирск, Россия) с буферными слоями ZnTe и CdTe. Общая толщина гетероэпитаксиальных слоев составляла от 5 до 9 мкм. Сигнал ФЛ возбуждался полупроводниковым лазером с длиной волны 1.03 мкм и регистрировался охлаждаемым фотоприемником на основе InSb. Спектры ФЛ записывались с использованием решеточного монохроматора в диапазоне температур 4.2-300 K. Спектры ОП записывались при температуре $300 \mathrm{~K}$ с использованием FTIR-спектрометра Shimadzu 8400.

Непосредственно после выращивания часть исследованных образцов продемонстрировала значительную степень разупорядочения твердого раствора. Это выражалось в существенном отличии положения края ОП и максимума спектра ФЛ от значений, которых можно было бы ожидать, исходя из номинального химического состава исследуемого материала, а также в аномально большом значении полуширины (ширины на половине высоты) линии межзонной (экситонной) ФЛ. Однако после термических отжигов, проведенных в диапазоне температур $260-300{ }^{\circ} \mathrm{C}$ в течение $2-6$ ч в атмосфере гелия при малом $\left(10^{-5}\right.$ ат) давлении паров ртути, оптические свойства этих образцов оказались близки к таковым, характерным для отожженных образцов, не выказывавших аномального разупорядочения после выращивания, а также для образцов, выращенных равновесным методом жидкофазной эпитаксией. В работе будет проанализирована возможная связь наблюдавшихся эффектов с различными типами дефектов, характерными для твердых растворов $\mathrm{HgCdTe}$, выращенных методом МЛЭ (в частности, с так называемыми V-дефектами [2]), и причины способности этих твердых растворов к «восстановлению» дальнего порядка кристаллической структуры в результате различных видов термических отжигов. Также будут рассмотрены вероятные причины формирования в слоях, выращенных на подложках из $\mathrm{Si}$, точечных дефектов, ответственных за формирование акцепторных состояний, глубина залегания которых может колебаться в пределах от 10 до 90 мэВ при отсчете от потолка валентной зоны. В частности, будет рассмотрена возможная связь подобных дефектов со структурными дефектами, формирующимися в гетероэпитаксиальных композициях со значительным рассогласованием параметров кристаллической решетки составляющих композицию слоёв.

\section{Литература}

[1] П.А.Бахтин, В.С. Варавин, С.А. Дворецкий и др. // ФТП. 2003. Т.37, вып.11. С.1369-1373.

[2] Yu.G. Sidorov, A.P. Anciferov, V.S. Varavin, et al., Molecular Beam Epitaxy of $\mathrm{Cd}_{\mathrm{x}} \mathrm{Hg}_{1-\mathrm{x}} \mathrm{Te}$, chapter 12 in Advances in Semiconductor Nanostructures: Growth, Characterization, Properties and Applications. Amsterdam: Elsevier; 2017, p. 297-323. 